REVIJA ZA ELEMENTARNO IZOBRAŽEVANJE JOURNAL OF ELEMNTARY EDUCATION

Vol. 11, No. 4, pp. 357-372, December 2018

\title{
LEARNINg Creative ARTS VIA INSTRUCTIONAL TELEVISION
}

\author{
Michael Olubunmi Odewumi ${ }^{1}$ Ayotunde Atanda Falade ${ }^{2} \&$ Adewale \\ Olusegun Adeniran ${ }^{3}$ \\ Potrjeno/Accepted \\ 6. 12. 2018 \\ Objavljeno/Published \\ 20. 12.2018 \\ ${ }^{1}$ Department of Educational Technology, Faculty of Education, University of Ilorin, \\ Ilorin, Nigeria \\ ${ }^{2}$ UiT - Department of Educational Technology, Faculty of Education. University of \\ Ilorin, Ilorin, Nigeria \\ ${ }^{3}$ Department of Science Education, University of Ilorin, Ilorin, Nigeria \\ CORRESPONDING AUTHOR/KORESPONDENČNI AVTOR \\ agbegilerebunmi2@gmail.com
}

Keywords:

Arts, audio-visual, creative arts,

instructional media, television, students.

Ključne besede: umetnost, avdioziualen, ustvarjalne umetnosti, izobraževalni mediji, televizija, učenci.

\begin{abstract}
Povzetek Television is an audio-visual box initially meant for entertainment, but it has developed to become a potential tool for instructions globally. The objectives of this study were to: identify television programme watched by the students and the students' response to creative arts learning via instructional television. The research used a descriptive cross-sectional survey method, and purposive sampling was employed to sample 10 schools in Ibadan metropolis, Nigeria. During the study questionnaire was administered to 350 students. The research question was answered and hypotheses tested using ANCOVA, and the t-test. The study concluded that the students fell about positive the use of television for learning in creative arts and the students should be encouraged to watch educational and enlightening programmes on television.
\end{abstract}

Učenje ustvarjalnih umetnosti z izobraževalnimi TV-vsebinami Televizija je avdiovizualna "škatla", ki je bila prvotno namenjena zabavi, vendar se je po vsem svetu razvila tudi v učinkovito orodje za izobraževanje. Cilji te raziskave so bili: identificirati televizijske oddaje, ki jih gledajo učenci, in njihov odziv na učenje ustvarjalnih umetnosti preko televizije. Študija je bila opisna raziskava medsektorske anketne metode. Uporabljen je bil namenski vzorec desetih šol v Ibadanu, glavnem mestu Nigerije. Pridobili smo odgovore na raziskovalna vprašanja, hipoteze pa smo preverili z analizo kovariance t-testa. Z raziskavo smo ugotovili, da učenci pozitivno sprejemajo televizijo kot pripomoček za

UDK/UDC 37.091.3:73/76 televizijskih izobraževalnih in informativnih oddaj. 


\section{Introduction}

The word Art has been phenomenal. The origin of art started with cave men. Art involves the bringing new things into reality. Wilson (2011) explained that art involves making skillful use of locally materials to produce objects for human use and pleasure, self-expression of various feelings or ideas in diverse forms. The literature, such as work by Fieser (2016) and Jacquette (2014) has defined art in various creative ways. For instance, Irivwieri (2009) explained that creative arts incorporate Visual Arts, Poetry, Drama and Music and are structured to the role of culture, within the specific cultural context of the learners. Aesthetic, creativity and musical active can also harnessed for educational goals. Similarly, the National Teachers Institute (2000) clearly stated that cultural and creative arts is a creative oriented course of study that merges field of creativity in Drama, Dance, Media Arts, Music and Fine Arts, taking into account the knowledge of the learners to remain in accordance with the literary locale of the child. Cultural creative arts serve to develop the language, idea, feeling, emotion and moods of learners.

According to Usman, Odewumi, Obotuke, Apolola and Ogunyinka (2014), creative arts instill in learners' good habit for using and preserving of artistic tools, materials and equipment. Creative arts inculcate intellect through practical and theoretical knowledge this provides adequate skills acquisition for higher arts education and develops interest in the learner's vocation and an opportunity for students to see the usefulness of art in other subject areas and in society (Odewumi, Okeke, Abdulhammed, Uzoma, Okuche, 2015). Overall, creativity has been the guiding spirit in which audiovisual materials for instruction.

Audio-visual media have become vital tool in civilization and in classrooms instruction. Empirical evidences about the use of audio-visual materials for instruction is inconclusive. For instance, Idris (2015) found that students taught with audiovisual improved greatly in comparison their counterpart taught with a conventional approach. Eze (2005) reported that students learn more easily and faster by audiovisual processes than by verbal explanations. A study by Shamsideen, (2016) confirmed that learners gain more through the senses than through verbal explanation, while a study by Rasul, Bukhsh, Batool (2011) explained that audio visual media are effective teaching devices that provides learners with realistic experiences. Akram and Malik (2012) portrayed audio-visual instruction as a bright, colorful experience that captures student attention via the sense organs of sight and hearing organs. Ashaver and Igyuve (2013) reported that audio-visual materials can function as a supplement to teachers' instruction and text books, it also stimulates 
learners thinking and understandings of multifarious values. Ofcom (2006) claims that audio-visual media is more viable for the entertaining and education of children. Bond and Garrahan (2015) established that technology brought a rapid increase in the development of multimedia for instruction, an area in which digital Television is prominent.

According to Mahesh, Aabid and Raslana (2013) television is an educational box, a learning imitator, and a medium for persuasive communications by individual. Television is an audiovisual tool that can address the scarcity in educational materials and that has metamorphosed instruction to become more flexible. The television era also rendered teaching to be more cautious, effective and less tension filled. Yusuf (2005) argued that digital television is an entrance to information communication. Garraham (2015) explained that television programmes pass through different production stages involving various experts, including script writing, music application, and creative inputs which the producer pre-clears to facilitate effective for instructional purposes.

Previous researches has revealed the effectiveness of television on students' acquisition of knowledge. Studies suggested that well designed television programmes stimulate and improve students' cognitive learning skill (Bryson, 2017). Several studies have stressed the relevance of television for learning. For example, Hassan and Daniyal (2013) conducted a study on the influence of educational television programs on students in city of Bahawalpur, Pakistan, the study proved that students do watch television and that it has a positive influence the students. Nwagbara and Nwammuo (2013) researched the impact of instructional television on the academic performance of senior secondary students in Anambra State, Nigeria. The study revealed that television programmes did developed students academically. In another study by Ahinda, Murundu, Okwara, Odongo and Okutoyi (2014) on the effectiveness of television on languages acquisition and academic performance of pre-school children, the author concluded that television had a negative effect on both academic achievement and languages acquisition among pre-school children. Also, Anatsui and Adekanye (2014) worked on television's impact on Nigerian youths and the implications for national development the study concluded that television significantly affected students' academically but the students' had strong negative perception about watching television. In essence, Nikken and Schols (2015) suggested that parents should monitor the television programmes to which their children are exposed.

Nevertheless, empirical studies on television have remained controversial among researchers. For instance, a study of Seels, Berry, Fullerton, \& Horn, (2001) stressed 
television as an audiovisual device for entertainment and an instructional provider both at home and in school. Nwagbara and Nwammuo (2013) affirmed that the potential of television instruction benefit education, exposes learners to constructive and cognitive learning habits, while offering meaningful entertainment and a means to skillful learning. Moreover, Pezdek \& Hartman (1983) explained that television provides learners with increased experience, knowledge and potential that may be needed in the future. Lemish (2007) advanced Piaget's four stages of cognitive development in learners and linked these with television knowledge acquisition. This has according to Duyile (2007) this has led to a long tradition of acknowledging usefulness of television for instructional purpose and its immensely positive influence on globally citizenship.

Moreover, Oguntuase (2008) explained that television provides potentially useful tip that are needed for instructions this author further mentioned the attribute of television in term of originality, theatre, sound production and colour blending all of which proves television to be an acceptable tool for audiovisual instructional in learning. Evans, Jordan, and Horner (2011) argued that television was more effective in teaching creatively and that it has a positive influence on other disciplines of the humanities, technology and the sciences. Anatsui and Adekanye (2014) claimed that television programmes brings the world closer to various homes and exposes individual to the values, norms and attitudes of different cultures. Shabiralyani, Hasan, Hamad, and Iqbal (2015) explained that television provides a useful scholarly resource for student creativity and that it holds the attention of learners. Kanazawa (2006) noted that television aid intelligent. In essence, it is clear that television as a potential medium of instruction helps to achieved academic goals and reduced poor academic performance among students.

Several studies have addressed poor academic performances among students. For example, Mlambo (2011) listed factors like age, gender, and family life as crucial factors affecting academic pursuit of learning. Conversely, Kaur, Chung, and Lee (2010) argued that age does not contribute significantly to learner performances especially in distance learning. Also, Banerjee (2016) confirmed that the existing relationship among age, academic achievement and gender differences is crucial for the academic achievement of learners. Another study by Olusola, Douglas, Aghimien, Emmanuel and Olushola (2016) stressed that family income exerts a powerful influence on the achievement of learners academically.

Moreover, previous studies have itemised the causes of poor students' performance, Tshabalala and Ncube (2013) noted that poor performances by students can be caused by a lack of good learning materials and by poor teaching 
methods. Alos, Caranto and David (2015) identified constant changes of school, teachers transfer and family separation as another possible factor. A study by Jayanthi, Balakrishnan, Ching, Latiff, and Nasirudeen (2014) similarly mentioned the scarcity of competent teaching personnel and inadequate teaching facilities. A study by Enu, Agyman and Nkum (2015) established the lack of self-motivation among both teachers and students as another factor. In conclusion, Akessa and Dhufera (2015) and Obidile, Amobi, Uzoekwe and Akuezilo (2017) reported that a lack of capital to procure needed equipment, poor quality texts, the explosive in students' number in classes, and teachers' experience combine with the socioeconomic background of students to form the main causes of poor academic performances among students.

Despite all these problems, television can still fill a gap, it encourages learning through cooperation and individually. Few studies on television and the creative arts in Nigeria. Although, content delivery is witnessing positive changes from a conservative method of delivery to technological development and innovation. Therefore, learners should be involved and encouraged in individual learning through a range of processes and methods. The essence by which television can improve the academic performance of learners in Nigeria is unknown. This study looks into the acquisition of creative arts through television among the Junior Secondary School Students in Ibadan, Oyo State. Nigeria.

\section{Research Questions}

The following questions were raised and answered to guide this study:

Do you watch television programmes?

How frequent do you watch television programmes?

Did you have interest in watch television?

Is there any difference among the students watching television for acquisition of knowledge or for fun and entertainment?

\section{Research Hypothesis}

These research hypotheses were formulated to guide the study

Hypothesis 1: There is no significant difference among the students watching television for acquisition of creative arts and those watching it for fun and entertainment.

Hypothesis 2: There is no significant difference in the male and female students watching television for the acquisition of creative arts and those watching it for fun and entertainment. 


\section{Methodology}

This study was a descriptive survey type. The population consisted of all junior school students of year three cultural and creative arts in Ibadan, Oyo State. Five hundred respondents including both female and male students were randomly selected from 10 Junior Secondary Schools in Ibadan. Fifty copies of the questionnaire were administered in each school visited. The study sampled was based on the following selection criteria: The city of Ibadan was chosen for the study because of the constant supply of electricity. Public junior secondary schools were selected where cultural and creative had been taught for at least ten years, with the availability of both materials and human resource on the ground. Finally, we noted students' report of having a television set at home and evidence of constant viewing. Therefore, 50 copies of the questionnaire were administered in each school, but only 350 of these were found to be valid out of those retrieved, and these were used for the study.

The questionnaire developed and designed for this study comprises of section A, B and C. 'A' includes the demography data of respondents, such as name of school, gender, age and so on. Section 'B' was used to obtain information on any television programme watched by the students. Section $C$ was sub-divided into three parts (i, ii, and iii). These sub-divisions are as follows:

- the frequency of television viewing for the acquisition of cultural creative arts, with students responding as being Highly Interested (HI), Average Interested (AI), Low level Interested (LLI) and Not Interested (NI).

- the influence of television viewing on the acquisition of cultural creative arts with students responding with Frequently Watched (FW) and Frequently Not Watched (FNW). Lastly, there was the structural questionnaire on television viewing for acquisition of cultural creative arts, and

- students watching television for the acquisition of cultural creative arts was subdivided into 10 items numbered 1 to 10 and patterned on the five point Likert type rating scale format of Strongly Agree (SA) - 5 points, Agree (A) - 4 points, Disagree (D) - 3 points Strongly Disagree (SD) - 2 points and Undecided (UD) $-1$.

To ensure perfection of the study instruments, the research instrument, was exposed to both content and face validity through the service of three University of Ilorin lecturers in the Department of Test Measurement and Evaluation, Educational Technology and Department of Library and Information Technology. 
Their constructive comments, corrections and suggestions were taken into consideration to amend the research instrument. Permission was sought from the principals of the schools visited before administering the questionnaire. The instrument was handled by the researcher and adequate instructions were explained to the students by the researcher before they responded to the questionnaire. Data generated were analyzed with frequency counts, mean and simple percentage inferential statistics. Also, percentages were used to determine the degree of significance and frequency of watching television programmes for the study based on the students' order of preferences.

Students responses about television viewing frequency. The data generated comprised the following categories of television programming Sports, Music, Movies and Entertainment, Culture and Lifestyle, Commerce and News, and Documentaries. The data were collected and analyzed in frequency counts, mean and percentages. Table 1 shows s students' frequency of watching particular types of television programmes.

Table 1: Students' Viewing Frequency of TV Programmes

\begin{tabular}{|c|c|c|c|c|c|c|c|}
\hline $\mathbf{S} / \mathbf{N}$ & Programmes & Watch & $\%$ & Not Watch & $\%$ & Overall & $\%$ \\
\hline 1 & Sport & 280 & 80 & 70 & 20 & 350 & 100 \\
\hline 2 & Music & 195 & 45 & 191 & 55 & 350 & 100 \\
\hline 3 & Movies \& Entertainment & 200 & 57 & 150 & 43 & 350 & 100 \\
\hline 4 & Life Culture and Style & 75 & 22 & 275 & 78 & 350 & 100 \\
\hline 5 & Commerce and News & 56 & 16 & 294 & 84 & 350 & 100 \\
\hline \multirow[t]{2}{*}{6} & Documentary & 130 & 37 & 220 & 63 & 350 & 100 \\
\hline & Total & 900 & 257 & 1199 & 343 & 2099 & 100 \\
\hline
\end{tabular}

In Table 1, it is evident that Sports with frequency counts of 280 responses, corresponding to $80 \%$ is the most frequent watching type of the programme while Commerce and News with 294 respondents, corresponding to $84 \%$ was most often not programming. Thus, the students watched sport more often than any other programming on the television. 
Table 2: Students Interest in View Television Programmes

\begin{tabular}{|c|c|c|c|c|c|c|c|c|c|}
\hline$\frac{Z}{\infty}$ & 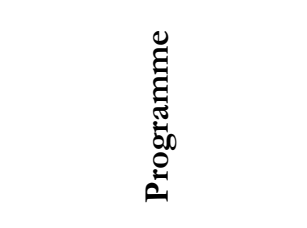 & 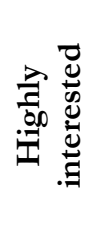 & $\partial^{0}$ & 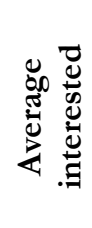 & $0^{\circ}$ & 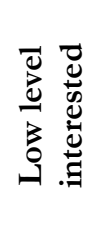 & $0^{\circ}$ & 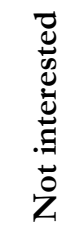 & $0^{\circ}$ \\
\hline 1 & Sport & 210 & 63 & 80 & 23 & 35 & 10 & 25 & 7 \\
\hline 2 & Music & 125 & 36 & 90 & 25 & 100 & 29 & 35 & 10 \\
\hline 3 & $\begin{array}{l}\text { Movies Or } \\
\text { Entertainment }\end{array}$ & 50 & 14 & 200 & 57 & 50 & 14 & 50 & 14 \\
\hline 4 & Life style & 120 & 34 & 75 & 21 & 35 & 10 & 40 & 11 \\
\hline 5 & News and Commerce & 200 & 57 & 64 & 18 & 39 & 11 & 47 & 13 \\
\hline 6 & Documentary & 120 & 34 & 100 & 29 & 30 & 9 & 100 & 29 \\
\hline & Total & 825 & 238 & 609 & 173 & 289 & 83 & 297 & 84 \\
\hline
\end{tabular}

In Table 2, it is clear that students are highly interested in watching Sport with 210 responses $(63 \%)$, while many fewer student report not watching of Sport on television 29 (7\%). Music arouses average level of interested for 200 (57\%), low level interested in 100 respondents (29\%) and aroused no interest at all in 100 respondents $(29 \%)$.

\section{Hypothesis Testing}

$\mathrm{Ho}_{1}$ : There is no significant difference among the students watching television for acquisition of creative arts and those watching it for fun and entertainment. This hypothesis was tested using ANOVA statistics to compare the students in watching television programming for learning. The hypothesis was tested at 0.05 level of significance as shown in Table 3.

Table 3: One Way ANOVA Result for Students Watching Television Programming for Acquisition of Creative arts

\begin{tabular}{llcccc}
\hline Source & $\begin{array}{l}\text { Type III Sum } \\
\text { of Squares }\end{array}$ & Df & Mean Square & F & Sig. \\
\hline Corrected Model & $7333.260^{\mathrm{a}}$ & 9 & 814.807 & 10.999 & .000 \\
\hline Intercept & 1017039.111 & 1 & 1017039.111 & 13729.241 & .000 \\
\hline Factor & 7333.260 & 9 & 814.807 & 10.999 & .000 \\
\hline Error & 25186.629 & 340 & 74.078 & & \\
\hline Total & 1049559.000 & 350 & & & \\
\hline Corrected Total & 32519.889 & 349 & & & \\
\hline
\end{tabular}

Table 3 indicates that the calculated $\mathrm{F}$ value of 10.999 is significant because the significant value of .000 is not bigger than 0.05 alpha levels. This result implies that there is a significant difference among students watching television programming 
for learning and those watching it for fun and entertainment. Therefore, the null hypothesis is rejected.

$\mathrm{Ho}_{2}$ : There is no significant difference in the male and female students watching television for the acquisition of creative arts and those watching it for fun and entertainment.

This hypothesis was tested using t-test statistics to compare the male and female student watching television programming for the acquisition of learning of Cultural Creative Arts. The hypothesis was tested at a 0.05 level of significance as shown in Table 4.

Table 4: Showing the t-test Statistics for Male and Female Television Programme Viewing Habits.

\begin{tabular}{ccccccc}
\hline Variables & No & Mean & sd & df & t & Sig \\
\hline Male & 130 & 53.90 & 9.56 & & & \\
\hline & & & & 348 & 009 & .993 \\
\hline Female & 220 & 53.91 & 9.73 & & &
\end{tabular}

Table 4 indicates that the calculated $t$ value of 009 is significant because the significant value of .993 is bigger than the 0.05 alpha levels. This result implies that there is no significant difference in mean scores of male and female students watching television programming for learning creative arts. Therefore, the null hypothesis is not rejected.

In other words, the result suggested that both male and female students view television in order to learn creative arts. In other to ascertain where the significant different lies, the mean for male and female students were compared, the means for male students (53.90) was slight lower than the mean for female students (53.91).

\section{Results}

The result of Hypothesis 1 implies that there is a significant difference among the students watching television programming for learning likewise, the result of Hypothesis 2 shows that both male and female students view television programming in order to learn creative arts. However, both results significantly show the positive attitude of students towards watching television for learning.

Moreover, the finding conformed with Moses (2008), Oji and Habibu (2011 and Anatsui, and Adekanye, (2014) whose studies yield significantly positive result concerning the academic performances of students watching for a few hours. The study is also in line with Adeniyi (2015) and Ocharo and Karani (2015) whose 
studies confirmed television as a positive influence on learning for various discipline on the school curriculum. Research by Oberiri (2016) and Aduwa-Ogiegbaen and Iyamu (2005) also revealed that television develops learners' intellect and creativity. The study further supported Orde (2012) who affirmed that children's learning through television can be positive and permanent. Another study Nazli, Çiğdem, Aylin Küntay, Fatoş (2008) confirmed the relatively significantly gain in cognitive skills for students learning through television.

Moreover, the report contradicts the study by Azeez, Aqeel Ashraf, SherJuni, Haider, Gujjar, Kareem, and Gill (2014) who established that excessive television watching in learner's leads to depression that can affect learners academically. Also, Hess and Goldman (1962) reporting low academic grades and problems in learning due to over indulgence in watching television. Moreover, research by Bliss (2013), and Singh and Gaurav (2013) also established that students that watching television performed poorly in reading. Likewise, Mullings (2012) established that revealed that watched film and television viewing had an adverse effect on the performance of students academically.

The findings agreed with those of Okpala, Awujo, and Okpala, (2016) whose study revealed that television consume much student time and limit their academic life. Also, Hassan and Daniyal (2013) and Baya and Mberia (2014) also established television as having as having a negative impact on students' academic grades. However, the finding contradicts those of Shin (2004) who findings revealed that the environment of the child has considerable influences on the child in respects of the television. Another study by Oyero and Oyesomi (2014) argued that children who watch television are basically week in psychomotor learning skills and therefore prose to obesity.

Overall the finding conforms with the findings of Popoola (2008) and Herman, Hopman and Sabiston (2015) whose studies reported that television distract students' attention and leads to excessively poor performance. The findings also accord with those from a study by Bushman and Anderson (2001) which stressed that students watching television have lower scores. Furthermore, Schmidt and Vandewater (2008) who study reported that students who watch television suffer from loss of attention when compared to other children.

Finally, the work by Mullings (2012) confirmed that students who watched television shows a decline in grades. Despite the aforementioned pros and cons concerning on television viewing, it is imperative to note that if television is monitored and judiciously used. It could develop the cognitive, affective and psychomotor domains in students. 


\section{Recommendations}

Based on the research, the following recommendations are forwarded:

1 Government should promote our cultural heritage, norms and values through television programmes.

2 Government should provide adequate information for teachers about educational and learning content on television.

3 Parents should monitor their children concerning the type of television programmes they should watch.

4 The Ministry of Education through the government should monitor educational programmes on television.

5 Workshops and seminars should be organized for television stations on the educational programming to be air

\section{References}

Adeniyi K. A. (2015). Television viewing patterns: implications for learners in Lagos state secondary schools. Journal of Scientific Research and Studies. 2(5), 119-125.

Aduwa-Ogiegbaen, S. E., \& Iyamu, E. O. S. (2005). Using information and communication technology in secondary schools in Nigeria: Problems and Prospects. Educational Technology \& Society, 8(1), 104-112.

Ahinda, A. A., Murundu, Z. O., Okwara, M. O., Odongo, B. C. \& Okutoyi, J. (2014). Effects of television on academic performance and languages acquisition of pre-school children. International Journal of Education and Research, 2(11), 493-502.

Akessa M., \& Dhufera A. G. (2015). Factors that influences students academic performance: A Case of Rift Valley University, Jimma, Ethiopia. Journal of Education and Practice, 6(22),55-63.

Alos, S. B., Caranto, L. C., David, J. J. T., (2015). Factors affecting the academic performance of the student nurses of BSU. International Journal of Nursing Science, 5(2), 60-65.

Anatsui, T. C. \& Adekanye, E. A. (2014). Television and academic performance of Nigerian youths: implications for national development. Journal of Economics and Sustainable Development, 5(10), 58-66.

Ashaver, D., \& Igyuve, S. M. (2013). The use of audio-visual materials in the teaching and learning. Processes in Colleges of Education in Benue State-Nigeria. IOSR. Journal of Research \& Method in Education (IOSR-JRME), 1(6), 44-55.

Azeez, F., Aqeel Ashraf, C., SherJuni, M., Haider, I., Gujjar, M.S., Kareem, J. \& Gill, M. A. A., (2014). The impact of electronic media on academic performance of female students. Asian Journal of Educational Research, 2(2), 15-23

Banerjee, P. M. (2016). A systematic review of factors linked to poor academic performance of disadvantaged students in science and maths in schools. Cogent Education (3), 1-17.

Baya, S. Y. \& Mberia, H. K. (2014). The Impact of Television Viewing in Influencing Adolescents Sexual Behaviour. International Journal of Scientific and Research Publications, 4(5), 1-4.

Bliss, K. (2013). Negative effects of television on the academic performance of a child. Available: http://www.livestrong.com/article (Accessed September $7^{\text {th }}$ 2017.)

Bond, Shannon and Garraghan, Matthew. (2015). Broadcasters fear falling revenues as viewers switch to on-demand TV, Available: FT.com (Accessed February 22 $2^{\text {th }} 2015$ ). 
Bryson, C. (2017). 7 Reasons why TV can be good for children. television is not necessarily a bad thing. Thought Co. Learn Something New Every Day. Retrieved on September 7, 2017 from https:/ / www.thoughtco

Bushman, B. J. \& Anderson, C. A. (2001). Media violence and the American public. Scientific facts versus media misinformation. American Psychologist, 56(6-7), 477-489.

Duyile, D. (2007). The media and educational development in Nigeria. A paper delivered at NTAETV symposium at Lagos on Monday, December 12 2007.

Enu, J, Agyman, O. K., \& Nkum D. (2015). Factors influencing students' mathematics performance in some selected colleges of education in Ghana. International Journal of Education Learning and Development, 3(3), 68-74.

Evans, C. A., Jordan, A. B., \& Horner, J. (2011). Only two hours?: A qualitative study of the challenges parents perceive in restricting child television time. Journal of Family Issues, 32(9), 1223-1244.

Eze, E. U. (2005). Effect of instructional materials on the academic performance of junior secondary school students in social studies. Unpublished PGDE Thesis. Imo State University-Nigeria

Fieser, J. (2016). The meaning of life. from Great Issues in Philosophy. Available: www.utm.edu/staff/jfieser/120 (Accessed September 7th 2017).

Garraham, M. (2015). "TV Networks Face Shaky Future in Fast-Changing Global Media Landscape.” Financial Landscape.” Financial Times, August 28, p. 16

Hassan, A., \& Daniyal, M. (2013). Impact of television programs and advertisements on school going adolescents: a case study of Bahawalpur city, Pakistan. Bulgarian Journal of Science and Education Policy, 7(1), 26-37.

Herman, K. M., Hopman, W. M., Sabiston, C. M. (2015). Physical activity, screen time and self-rated health and mental health in Canadian adolescents. [CrossRef] [PubMed] Prev. Med. 2015 (73), 112-116.

Hess, R. D. \& Goldman, H. (1962). Parents' Views of the Effect of Television on Their Children. Child Development, 33(2),411-426.

Idris, A. O. (2015). The effects of audio-visual materials in the teaching and learning of the speaking skill in junior secondary schools. International Journal of Social Science and Humanities Research, 3(3), 50-58.

Irivwieri, G. O. (2009). The implementation of the creative arts curriculum in secondary schools in Nigeria. An International Multi-Disciplinary Journal, Ethiopia, 3(3), 342-358.

Jacquette, D. (2014). Art, expression, perception and intentionality. Journal of Aesthetics and Phenomenology, 1(1), 63-90.

Jayanthi, S. V., Balakrishnan, S., Ching, A. L. S., Latiff, N. A. A, \& Nasirudeen, A. M. A. (2014). Factors contributing to academic performance of students in a tertiary institution in Singapore. American Journal of Educational Research, 2 (9), 752-758.

Kanazawa, S (2006). Why the less intelligent may enjoy Television more than the more Intelligent. Journal of Cultural and Evolutionary Psychology, 4(2006)1, 27-36.

Kaur, K., Chung, H. T. \& Lee, N. (2010). Correlates of academic achievement for master of education students at Open University Malaysia. Paper presented in 6th PanCommonwealth Forum on Open Learning, 24th-28th November, 2010, Kochi, India.

Lemish, D., (2007). Children and Television: A Global Perspective, Oxford: Blackwell.

Mahesh C. G., Aabid Nabi, A. \& Raslana, R. (2013). Role of television in child. Journal of Mass Communication Journalism, 3(3),1-5. 
Mlambo, V. (2011). An analysis of some factors affecting student academic performance in an introductory biochemistry course at the University of the West Indies. Carribbean Teaching Scholar, 1, 79-92.

Mullings, N. (2012). Reality Television and its Effect on the Academic Achievement Of Inner-City High School Students. A Thesis Presented to the Faculty in Communication and Leadership Studies School of Professional Studies Gonzaga University. In Partial Fulfilment of the Requirements for the Degree Master of Arts in Communication and Leadership Studies.

Moses, A. M. (2008). Impact of viewing on young children's literacy development. Journal of Early Childhood Literacy, 8(1), 67-102

National Teachers Institute (2000). Course Book on Cultural and Creative Arts. NCE/DLS cycle 1, 2, 3 \& 4. Pes.1, 2, 3 \& 4.

Nazli. B., Çiğdem K., Aylin, C. K., Fatoş, G. (2008). Effects of an educational television program on preschoolers: Variability in benefits. Journal of Applied Developmental Psychology, 29(5), 349_ 360.

Nikken, P., \& Schols, M. (2015). "How And Why Parents Guide The Media Use Of Young Children". Journal of Child and Family Studies, 24(11), 3423-3435.

Nwagbara, G. U. \& Nwammuo, A. N. (2013). Instructional television programmes and academic performance of senior secondary school students in Anambra State, Nigeria. African Journal Online (AJOL) African Research Review, 7(2), 329-349.

Oberiri, D. A. (2016). Influence of television programmes on youth dressing pattern in Nigerian tertiary institutions, Global Journal of Human-Social Science, 16(6), 1-8.

Obidile. J. I., Amobi, S.C., Uzoekwe, H. E., and Akuezilo, J. A, (2017). Perceived factors influencing academic performance of students in accounting in secondary schools in Anambra State. IOSR Journal of Humanities and Social Science, 22(2), 96-99.

Ocharo, M. G., \& Karani, S. E. (2015). Effects of mass media on the academic development of children in primary schools in Kenya: A Case Study of St. Alloys Junior Academy. International Journal of Novel Research in Education and Learning, 2(2), 11-18.

Odewumi, O., Okeke, F., Abdulhammed, A., Uzoma, C., Okuche, D. (2015). Cultural and Creative Arts for Basic Schools. Osogbo. Nigeria. Paulmac Publishers,

Ofcom (2006). Media Literacy Audit: Report on media literacy amongst children, London: Ofcom Available:http://www.Ofcom.org.uk/advice/media_literacy/medlitpub/medlitpubrss/ch ildren/children.pdf (Accessed 20 ${ }^{\text {th }}$ October 2006).

Oguntuase, F. Z. (2008). Implication of copyright provision for literacy work in films and video for libraries, Nigeria Schools. African Journal Online (AJOL). Nigerian school library Journal, (7), 87-99

Okpala, I. M., Awujo, C. G. \& Okpala, A. N. (2016). The influence of television viewing on adolescent behaviour among public secondary school students in Obio/Akpor LGA in Rivers State. Journal of Education and Practice, 3(7), 142-151.

Olusola, S., Douglas, O., Aghimien, O., Emmanuel, A., \& Olushola, O. E. (2016). Factors affecting performance of undergraduate students in construction related disciplines. Journal of Education and Practice, 7(13), 55-62.

Oji, S. E. \& Habibu, I. (2011). The Role of Schools and Public Libraries in Promoting Reading Habit among Children and Adolescents in Nigeria. Information and Knowledge Management, 1(4), 33-40. 
Pezdek, K. \& Hartman, E. F. (1983). Children's Television Viewing: Attention and Comprehension of Auditory versus Visual Information. Child Development, 54(4), 1015-1023.

Oyero, O. S., \& Oyesomi, K. O., (2014). Perceived influence of television cartoons on Nigerian children. Estudos em Comunicação, No. 17, 93 -116.

Orde, H. v. (2012). Children, learning, and educational TV. An overview of selected research results. Research documentation (TELEVIZION), 38-41.

Popoola, A. A. (2008). Effects of television and radio distractions on undergraduate students mathematics test performance. Pakistan Journal of Social Sciences, 5 (5), 407- 410.

Rasul, S., Bukhsh, Q. \& Batool, S. (2011). A study to analyse the effectiveness of audio visual aids in teaching learning processes at university level. Procedia-Social and Behavioural Sciences, 28(2011), 78-81.

Schmidt, M. E., \& Vandewater, E. A. (2008). Media and attention, cognition, and school achievement. Future Child. 18(1), 63-85.

Seels, B., Berry, L. H., Fullerton, K. \& Horn, L. J. (2001). Research on Learning from Television. The handbook of research for Educational Communication and Technology. North Stonelake Drive, Bloomington.

Shabiralyani, G., Hasan, K. S., Hamad N, Iqbal, N. (2015). Impact of visual aids in enhancing the learning process case research: District Dera Ghazi Khan. Journal of Education and Practice, 6(19), 226-233.

Shamsideen, S. A. (2016). Impact of audio-visual materials in the dissemination of knowledge for facilitators in some selected literacy centres in Oshodi/Isolo Local Government Area. African Educational Research Journal, 4(1), 19-24.

Shin, N. (2004). Exploring pathways from television viewing to academic achievement in school age children. Journal of Genet. Psychol., 165(2004), 367-382.

Singh, A. \& Gaurav, S. (2013). Television Exposure and Academic Skills of Children: New Findings from India. Journal of Communication Technology and Human Behaviors (2013), 1-24.

Tshabalala, T. \& Ncube, A. C. (2013). Causes of poor performance of ordinary level pupils in mathematics in rural secondary schools in Nkayi District. Nova Journal of Medical and Biological Sciences, 1(1), 4-14.

Usman, A., Odewumi, O., Obotuke, E., Apolola, O \& Ogunyinka, C. O. (2014). Cultural and Creative Arts Book One for Junior Secondary Schools. Ibadan Nigeria. Spectrum Books Limited.

Wilson, J. (2011). Creative Arts Research: A long path to acceptance. Australian Universities' Review, 53(2), 76-68.

Yusuf, M. O. (2005). Information and communication technology and education: Analysis of the Nigeria National Policy for Information Technology. International Education Journal, 6 (3), 316-321.

\section{Authors}

\section{Odewumi Michael Olubunmi (PhD)}

c/o Oddelek za izobraževalno tehnologijo, Pedagoška fakulteta, Univerza Ilorin, Ilorin, Nigeria, e- pošta: agbegilerebunmi2@gmail.com

c/o Department of Educational Technology, Faculty of Education, University of Ilorin, Nigeria, e-mail: agbegilerebunmi2@gmail.com 


\section{Falade Ayotunde Atanda (PhD)}

Oddelek za izobraževalno tehnologijo, Pedagoška fakulteta, Univerza Ilorin, Ilorin, Nigeria e-pošta: falade.aa@unilorin.edu.ng C/o Department of Educational Technology, Faculty of Education, University of Ilorin. Ilorin. Nigeria.

e-pošta: adeniransegun67@yahoo.com

\section{Adeniran Adewale Olusegun (PhD)}

C/o Oddelek za izobraževalne znanosti, Pedagoška fakulteta, Univerza Ilorin, Ilorin, Nigeria. e-pošta: adeniransegun67@yahoo.com

C/o Department of Science Education, Faculty of Education, University of Ilorin. Ilorin. Nigeria. e-pošta: adeniransegun67@yahoo.com 